COMMON DRIVERS OF TRANSNATIONAL TERRORISM: PRINCIPAL COMPONENT ANALYSIS

\author{
Khusrav Gaibulloev \\ Todd Sandler \\ and \\ Donggyu Sul ${ }^{*}$
}

Forthcoming Economic Inquiry, 2013 
JEL Codes: C38, H56

\section{Common Drivers of Transnational Terrorism: Principal Component Analysis}

Khusrav Gaibulloev, Todd Sandler and Donggyu Sul

This paper applies principal component analysis to decompose transnational terrorism during 1970-2007 into common (worldwide) and idiosyncratic (country-specific) factors. Regardless of alternative thresholds and filtering procedures, a single common factor is related to individual countries’ transnational terrorist events. Based on a conventional criterion, Lebanon’s transnational terrorism is the key common driver of global transnational terrorist incidents. With a more conservative criterion, four additional countries - USA, Germany, Iraq, and the United Kingdom - are core countries in explaining cross-sectional correlation across 106 countries' transnational terrorism. The analysis shows that there is a marked cross-sectional dependence among transnational terrorist incidents worldwide. 


\section{COMMON DRIVERS OF TRANSNATIONAL TERRORISM: PRINCIPAL COMPONENT ANALYSIS}

\section{INTRODUCTION}

Ever since the skyjackings of four wide-bodied planes on September 11, 2001

(henceforth 9/11), economists have displayed a strong research interest in terrorism. Theoretical and empirical papers have investigated myriad aspects of terrorism - e.g., the economic consequences of terrorism, the impact of terrorism on economic development, the root causes of terrorism, and the effectiveness of counterterrorism policies (see the literature survey by Enders and Sandler, 2012). This research has derived some guiding principles. First, the macroeconomic consequences of terrorism are generally quite small and of a short-term nature for most economies. Like crime, terrorism is anticipated to have a local influence because property damage is typically limited and few people die - on average, 420 people lost their lives annually from transnational terrorist attacks since 1968 (Sandler et al., 2009). Second, large diversified economies are particularly able to endure terrorism with minimal repercussions as economic activities transfer from terrorism-prone to safer sectors. Third, small developing countries are more inclined to suffer adverse economic effects from terrorism (Keefer and Loayza, 2008). Fourth, in cross-sectional and panel regressions, transnational terrorism has had a small but significant impact on economic growth (Blomberg et al., 2004; Gaibulloev and Sandler, 2008, 2011; Tavares, 2004). Fifth, the root cause of terrorism is not poverty (Gassebner and Luechinger, 2011; Krueger and Maleckova, 2003; Piazza, 2011); unpopular foreign policy decisions appear to be a significant cause of transnational terrorism (Savun and Phillips, 2009). Sixth, actions to protect against specific types of terrorist attacks (e.g., metal detectors in airports to curb skyjackings) or to guard specific kinds of targets (e.g., government officials) result in terrorists substituting into other modes and targets of attacks (Brandt and Sandler, 2010; Enders 
and Sandler, 1993). Seventh, terrorism can influence the outcome of national elections (Gassebner et al., 2008, 2011).

The primary purpose of this paper is to apply modern principal component analysis to identify common (worldwide) and idiosyncratic (country-specific) factors that influence transnational terrorism involving two or more countries. Our main goal is to identify any comovement of transnational terrorism across countries, which has not been previously investigated. Principal component analysis is a statistical method to estimate the most influenced common stochastic series by analyzing cross-sectional correlation. For our particular application, principal component analysis identifies if there are influences that commonly or generally affect the dynamic co-movement of transnational terrorist attacks in the sample countries. If one or more common factors are estimated, then we relate these factors to the transnational terrorist attacks in the sample countries to ascertain whether some countries’ transnational terrorist campaigns drive attacks worldwide. Principal component analysis also indicates which countries’ transnational terrorism is driven by considerations specific to them and, thus, independent of attacks occurring abroad. Such countries likely confront perpetrators who are not driven by grievances, ideologies, or resources shared with groups abroad - hence, the notion of idiosyncratic factors.

The principal component analysis here finds a single common factor for transnational terrorism during 1970-2007, which we then relate by our methodology to the transnational terrorist campaigns in some specific countries. In fact, all co-movements of transnational terrorism across countries are explained by just five countries' transnational terrorist attacks. Among them, Lebanon’s transnational terrorist attacks explain most of the worldwide comovement of transnational terrorism, with the other four countries - United States, Germany, Iraq, and the United Kingdom - explaining the remainder. The five core countries reflect, to 
different degrees, the influence of the leftist and fundamentalist terrorists, who have dominated transnational terrorism during this period (Hoffman, 2006; Rapoport, 2004). These countries’ transnational terrorist attacks may have had this common influence on worldwide transnational terrorism through a demonstration effect, shared grievances, common terrorist perpetrators (e.g., al-Qaida and Abu Nidal Organization), or assets (i.e., people and property) abroad. For example, US assets at home and abroad will attract terrorist attacks worldwide by terrorist groups with a grievance against US policy, thereby resulting in a cross-sectional dependence among some countries' transnational terrorist attacks. At times, this co-movement may have arisen from a country’s foreign policy decisions - e.g., left-wing terrorists’ reacted globally to the US-Vietnam War. For Lebanon, this co-movement may have stemmed, in part, from many resident terrorist groups that trained in Lebanon and attacked there and elsewhere. The findings also indicate which regions and countries are influenced by country-specific drivers. Transnational terrorismplagued Colombia is almost entirely influenced by idiosyncratic factors, as is Liberia, Nicaragua, Guyana, and Gabon.

The identification of common and idiosyncratic factors of transnational terrorism has important policy implications. The presence of a common driver suggests that any war on transnational terrorism requires some international collective action. Moreover, we also know which countries have the biggest stake in this collective action; namely, those countries that are most affected by the common factor. In contrast, countries primarily influenced by idiosyncratic factors have much less to gain from this international cooperation, since their transnational terrorism is not dynamically affected by transnational terrorist attacks abroad. By knowing the common drivers of transnational terrorism, the most-influenced countries will better understand where they need to concentrate their counterterrorism efforts. Future studies can apply other methods to establish the root causes of this cross-sectional dependence. Moreover, the results 
here raise a caution to panel studies (e.g., those investigating the adverse influence of terrorism on growth) that cross-sectional dependence must be taken into account for unbiased results. ${ }^{1}$

The remainder of the paper contains five sections. Section II considers why transnational terrorist activities may be cross-sectionally correlated. In Section III, we present a procedure for determining the common factors of transnational terrorism. This procedure estimates the number of common factors and then identifies their underlying determinants in terms of countries' transnational terrorist campaigns. The data are presented in Section IV, followed by the empirical factor analysis of transnational terrorism in Section V. Section VI contains concluding remarks.

\section{WHY TRANSNATIONAL TERRORIST ACTIVITIES ARE CROSS-SECTIONALLY}

\section{CORRELATED}

There are many reasons to anticipate that transnational terrorist activities are crosssectionally correlated. Since the start of the modern era of transnational terrorism in 1968, terrorists have shared ideologies - the leftists sought to overthrow capitalist governments, while the fundamentalists have followed a fatwa issued against the "enemies” of Islam. These common ideologies and calls to action motivated terrorists to strike in concert against target countries. Some political events have simultaneously resulted in attacks in many countries e.g., a spate of terrorist attacks followed the Arab-Israeli conflicts, the US retaliatory raid against Libya in April 1986, the Gulf War in January 1991, and the Abu Ghraib prison revelations in April 2004 (Brandt and Sandler, 2009; Enders and Sandler, 1993). Moreover, countries’ attacks may be correlated owing to diverse terrorist groups receiving training in just a few countries camps in Jordan, Lebanon, Afghanistan, and Yemen trained terrorists since the 1970s (Alexander and Pluchinsky, 1992; Hoffman, 2006). In the 1990s, al-Qaida established terrorist training 
camps in Afghanistan with the intent to strike the interests of a set of enemy countries at home and abroad. With concentrated training facilities, terrorists grew to share common modes of attack and distain for similar countries and alleged wrongs.

As targeted countries responded to attacks through defensive or protective measures, the terrorists reacted by seeking out softer targets where they could hit the protected countries' interests. Thus, terrorist attacks and the ensuing countermeasures in one country led to attacks in other less fortified countries (Enders and Sandler, 2006). Cross-country correlations also arose because terrorists have cells in multiple countries - e.g., al-Qaida affiliates circle the globe. Hezbollah and other Middle Eastern groups engaged in attacks outside of the region - e.g., Hezbollah blew up the Israeli embassy in Buenos Aires on March 17, 1992 (US Department of State, 1993). The same was true for many of the European leftist terrorists, such as the Red Army Faction (RAF), which operated within and outside of Germany. Throughout the 1970s and 1980s, Middle Eastern terrorism spilled over to Europe, where terrorists tried to capture the world stage through greater media exposure for their cause in Western countries with freer media and greater audiences (US Department of State, various years).

Cross-country correlations of transnational terrorist attacks may also stem from terrorists copying successful attack innovations - e.g., suicide car bombings, first used in Lebanon in 1983, were later used elsewhere - e.g., Sri Lanka (Horowitz, 2010; Pedahzur, 2005). Similarly, counterterrorism innovations can reduce terrorist incidents worldwide - e.g., the introduction of metal detectors in airports reduced greatly the number of skyjackings worldwide (Enders and Sandler, 1993, 2012). Additionally, state sponsorship of terrorism, beginning in the late 1970s, meant that terrorist acts in one country could be correlated with acts in other countries - e.g., the Abu Nidal Organization served as a terrorist group for hire for state sponsors and, as such, operated in many countries (Hoffman, 2006). 
This anticipated cross-sectional dependence means that transnational terrorism may best be dealt with by a set of targeted countries, because their actions will have spillover effects beyond their borders. To gauge this cross-sectional dependence, we apply approximate common factor analysis approach, which is explained in the next section.

\section{COMMON FACTOR ANALYSIS OF TRANSNATIONAL TERRORISM}

The co-movement of terrorism for the countries $i$ and $j$ can be captured by the correlation coefficient between the two countries' transnational terrorist attacks. Let $\tau_{i t}$ be the number of terrorist attacks in country $i$ at time $t$. The co-movement of terrorist attacks in the two countries can then be statistically summarized by the following correlation statistic:

$$
\rho_{i j}=\frac{E\left[\frac{1}{T} \sum_{t=1}^{T}\left(\tau_{i t}-\mu_{i}\right)\left(\tau_{j t}-\mu_{j}\right)\right]}{\sqrt{E\left[\frac{1}{T} \sum_{t=1}^{T}\left(\tau_{i t}-\mu_{i}\right)^{2}\right] E\left[\frac{1}{T} \sum_{t=1}^{T}\left(\tau_{j t}-\mu_{j}\right)^{2}\right]}},
$$

where $\mu_{i}$ is the mean and $t=1, \ldots, T$ denotes the number of time periods. If there is no crosscountry dependence, which implies that the expectation of the sample covariance [numerator of Equation (1)] is zero, then transnational terrorism is purely country specific. However, there are many reasons to expect cross-country correlation across many countries (see Section II). Such co-movement of transnational terrorism across sovereign countries may be due to a few common or worldwide factors. We decompose annual transnational terrorist events in country $i$ into common $\left(G_{i t}\right)$ and idiosyncratic $\left(\tau_{i t}^{o}\right)$ components:

$$
\tau_{i t}=\mu_{i}+G_{i t}+\tau_{i t}^{o}
$$

The common component is allowed to vary across countries, because the same common or worldwide component may affect terrorist activity for each country differently. The 
idiosyncratic component is uniquely associated with the country investigated. The decomposition of transnational terrorism into common and idiosyncratic components is novel to this literature. Hence, we now present an approximate common factor representation, which has been recently developed in econometrics.

The cross-correlation between transnational terrorist attacks in country $i$ and those elsewhere in the world can be captured by the following simple latent model:

$$
\tau_{i t}=\mu_{i}+\lambda_{i}^{\prime} F_{t}+\tau_{i t}^{o},
$$

where $\lambda_{i}$ is a $K \times 1$ vector of factor loading coefficients, $F_{t}$ is a $K \times 1$ vector of $K$ common factors, and $\tau_{i t}^{o}$ is a country-specific or idiosyncratic component. In Equation (3), the second right-hand term represents the common component in Equation (2). Equation (3) is called the approximate common factor representation, where common factors, $F_{t}$, are independent of idiosyncratic components, $\tau_{i t}^{o}$. Typically, the cross-sectional correlation among $\tau_{i t}^{o}$ is assumed to be negligible or zero. This approximate common factor model has been rapidly developed and is much more flexible than the classical factor analysis. The latter considers either the case of large $T$ and a fixed number of countries, $N$, or the case of fixed $T$ and a large number of countries, $N$. Moreover, classical factor analysis assumes that the number of common factors is usually known (see Anderson, 1984). The approximate common factor model does not make these strong assumptions and provides well-developed asymptotic properties for the estimated common factors and factor loading coefficients.

To provide an economic interpretation for each stochastic component in the latent model, we first consider the overall covariance between terrorism in countries $i$ and $j$ given by

$$
E\left[\frac{1}{T} \sum_{t=1}^{T}\left(\tau_{i t}-\mu_{i}\right)\left(\tau_{j t}-\mu_{j}\right)\right]
$$




$$
\begin{aligned}
& =E\left[\frac{1}{T} \sum_{t=1}^{T}\left(\lambda_{i}^{\prime} F_{t} \cdot \lambda_{j}^{\prime} F_{t}\right)\right]+E\left[\frac{1}{T} \sum_{t=1}^{T}\left(\tau_{i t}^{o} \tau_{j t}^{o}\right)\right]+E\left[\frac{1}{T} \sum_{t=1}^{T}\left(\lambda_{i}^{\prime} F_{t} \cdot \tau_{j t}^{o}+\lambda_{j}^{\prime} F_{t} \cdot \tau_{i t}^{o}\right)\right] \\
& =E\left[\frac{1}{T} \sum_{t=1}^{T}\left(\lambda_{i}^{\prime} F_{t} \cdot \lambda_{j}^{\prime} F_{t}\right)\right]=E\left[\lambda_{i}^{\prime}\left(\frac{1}{T} \sum_{t=1}^{T} F_{t} F_{t}^{\prime}\right) \lambda_{j}\right],
\end{aligned}
$$

since $E\left(\frac{1}{T} \sum_{t=1}^{T} \tau_{i t}^{o} \tau_{j t}^{o}\right)=E\left[\frac{1}{T} \sum_{t=1}^{T}\left(\lambda_{i}^{\prime} F_{t} \cdot \tau_{j t}^{o}+\lambda_{j}^{\prime} F_{t} \cdot \tau_{i t}^{o}\right)\right]=0$ for each $i$ and $j$. It is, however, not possible to identify uniquely the original factor loadings and factors, because we can always write

$$
\lambda_{i}^{\prime} F_{t}=\left(\lambda_{i}^{\prime} H\right)\left(H^{-1} F_{t}\right)=\lambda_{i}^{* \prime} F_{t}^{*}
$$

Hence, we normalize the common factor such that $\frac{1}{T} \sum_{t=1}^{T} F_{t} F_{t}^{\prime}=I_{K}$. That is, the variance of $F_{s t}$ is assumed to be unity for $s=1, \ldots, K$. Given this normalization, we can now evaluate the economic meaning of factor loadings. Observe that

$$
E\left[\frac{1}{T} \sum_{t=1}^{T}\left(\tau_{i t}-\mu_{i}\right)\left(\tau_{j t}-\mu_{j}\right)\right]=E\left(\lambda_{i}^{\prime} \lambda_{j}\right)
$$

which implies that the overall covariance between the transnational terrorism of the two countries can be captured by factor loadings.

Next, consider the dynamic variation between transnational terrorism in two countries. For convenience, assume that $K=1$. Further suppose that the common factors during the first three periods are zeros, but that the common factor during the last period is unity. That is, $F_{t}=(0,0,0,1)^{\prime}$. In addition, idiosyncratic terrorism, $\tau_{i t}^{o}$, is randomly distributed. Then at $t=1,2,3$, there will be no cross-correlated terrorism activity because the common factors are zeros even though $\lambda_{i} \neq 0$. However, at time $t=4$, transnational terrorism in country $i$ is 
correlated with that in country $j$ by $E\left(\lambda_{i}^{\prime} \lambda_{j}\right)$. The common factors, thus, provide a dynamic correlation structure across countries for transnational terrorism, given factor loadings. More important, the common factors for transnational terrorism become the dynamic source of worldwide terrorism. Of course, not all countries' transnational terrorism need display this cross correlation; e.g., the small amount of transnational terrorism in Iceland is unlikely to be correlated with worldwide terrorism activities.

The thorniest issue for either classical or approximate common factor analysis is the identification of the unknown common factors. Without knowledge of the source of the common factors, common factor analysis becomes a pure statistical exercise. In this paper, we extend this statistical exercise and identify the estimated common factors by using a novel method. Typically, economists search beyond macroeconomic variables to explain common behaviors; e.g., empirical studies on the determinants of terrorism investigate economic, social, and political variables that are correlated with transnational terrorism (e.g., Abadie, 2006; Piazza, 2011). We are not doing this here; rather, we are asking whether transnational terrorism campaigns in a few key countries are the drivers of transnational terrorism worldwide. Insofar as we do not know the core countries whose transnational terrorist activities influence the rest of the world, we are first using the approximate common factor model to estimate the common factors and then to identify the core countries. This novel approach is now explained in further detail.

\section{A. Estimation of the Common Factors}

All empirical studies on the approximate common factor models start with the estimation of the number of common factors. Without knowing the number of common factors, we are not able to identify the common factors. We use the Bai and Ng (2002) method to estimate the 
number of factors. ${ }^{2}$ Before doing so, we standardize the panel data, which implies that we are using the correlation, rather than covariance, matrix.

Bai and Ng (2002) proposed three information criteria based on the estimated eigenvalues from the covariance matrix. Let the loss function be

$$
L(r)=\frac{1}{N T} \sum_{i=1}^{N} \sum_{t=1}^{T}\left(\tau_{i t}-\mu_{i}-\sum_{s=1}^{r} \lambda_{i s} F_{s t}\right)^{2},
$$

where $N$ denotes the number of sample countries and $r$ denotes the estimated number of common factors. Bai and Ng (2002) suggested the following Information Criteria (IC) with respect to $r$ :

$$
\begin{aligned}
& I C 1=\ln L(r)+r \frac{N+T}{N T} \ln \left(\frac{N T}{N+T}\right), \\
& I C 2=\ln L(r)+r \frac{N+T}{N T} \ln \left(C_{N T}^{2}\right), \text { and } \\
& I C 3=\ln L(r)+r\left(\frac{\ln C_{N T}^{2}}{C_{N T}^{2}}\right),
\end{aligned}
$$

where $C_{N T}=\min [\sqrt{N}, \sqrt{T}]$. Bai and $\operatorname{Ng}$ (2002) showed that IC1 and IC2 outperform IC3, and Greenaway-McGrevy et al. (2010, 2011) established that IC2 is the best performer and that IC1 slightly overestimates the number of common factors. Therefore, we use only IC1 and IC2 when we estimate the number of common factors. Later, we use IC3 to identify the determinants of the common factors, because we want a more conservative criterion when finding these determinants. Actual usage of these criteria is like the Bayesian information criterion (BIC) or Akaike information criterion (AIC): choose the maximum number of factors and then minimize the criteria. We set the maximum number to be six.

It is important to note that even IC1 and IC2 overestimate the number of factors when the idiosyncratic components have persistent serial dependence. In this case, filtering - pooled 
AR(1) or first difference - is required to estimate the number of factors; however, filtering nonpersistent data may result in overestimation. ${ }^{3}$ We later show that filtering is unnecessary for transnational terrorism data, because the estimated number of common factors is always less than six.

In many periods, there are zero incidents of transnational terrorism for many of the sample countries. Excluding countries, where there is little transnational terrorism, increases the cross-sectional dependence, which promotes an accurate estimate of the factor number.

However, this exclusion may lose estimation robustness if too many countries are excluded. ${ }^{4}$ Consequently, we check results with various censored percentages. First, we define the index function $\psi_{i t}$ for transnational terrorism as

$$
\psi_{i t}=1\left\{\tau_{i t}>0\right\},
$$

which denotes the periods where there are one or more transnational terrorist attacks, so that the total frequency of terrorist attacks (i.e., periods with nonzero incidents) for country $i$ is given by $c_{i}=\sum_{t=1}^{T} \psi_{i t}$. Second, we construct the panels along with the values of $c_{i}$. That is, we construct various panels $\left\{\tau_{i t}\right\}_{i \in H}$ based on $c$, such that

$$
i \in H \text { if } c_{i} \geq c \text {. }
$$

Obviously, as $c$ increases, the total number of cross-sectional units in the corresponding panel decreases because a greater number of nonzero terrorist attack periods are required for inclusion in the panel.

Once the number of common factors is determined, we then estimate the common factors and factor loadings by using principal component analysis. We construct a correlation matrix using Equation (1), so that the estimated $T \times K$ eigenvectors become the estimated common factors. The factor loading coefficients are then estimated from regressing transnational 
terrorism on a constant and the estimated common factors for each country. The coefficients on the estimated common factors are the factor loadings for the country.

\section{B. Identifying the Common Factors}

Common factor analysis has been used infrequently in economics because it does not provide any explanation for the underlying determinants of the common factor(s). Here, we identify the common factor by using a simple but intuitive method. When, e.g., a price leader sets the market price, the prices for the rest of the firms would be highly correlated with the leader's price. Similarly, we ask whether we can find a few core countries whose transnational terrorist incidents determine the common factor for worldwide transnational terrorism. Our thinking is that transnational terrorism is being driven or influenced by hot spots of terrorist activity.

Suppose that $\tau_{1 t}$ is the most important driver of cross-sectional dependence in $\tau_{i t}$, then the common factor model can be rewritten as

$$
\tau_{i t}=a_{i}+\beta_{i} \tau_{1 t}+\tau_{i t}^{o} \text { for } i \neq 1
$$

However, the problem is that we do not know which countries are the main drivers. In order to find the potential core determinant countries for the first common factor, we run

$$
\hat{F}_{1 t}=\alpha+\sum_{s \in \zeta_{m}} b_{s} \tau_{s t}+\sum_{j=2}^{r} \omega_{j} \hat{F}_{j t}+\varepsilon_{t}
$$

where $\zeta_{m}$ is a subset of $m$ potential countries responsible for $\hat{F}_{1 t}$, which is the primary determinant for the co-movement of transnational terrorism; and $r$ denotes the estimated number of common factors. We can estimate $r$, but we do not know the number of core countries, $m$. Also, note that the true value of $\omega_{j}$ is zero, because the estimated first common factor must be 
independent of other common factors. However, we must project the influence of the other common factors on $\tau_{\text {st }}$. Suppose that $r=1$ and $m=1$. Then we run $\hat{F}_{1 t}=\alpha+b_{s} \tau_{s t}+\varepsilon_{t}$ for each $s$ to find the country that minimizes the sum of squares residuals (SSR). Let $\tau_{1 t}^{*}$ denote the terrorist attacks in the resulting country that minimizes SSR. Next, we increase $m$ by 1 (now $m=$ 2) and estimate the next potential core country by running $\hat{F}_{1 t}$ on a constant, $\tau_{1 t}^{*}$, and the transnational terrorist incidents in one additional country. We run $N-1$ individual regressions and choose the second core country by minimizing SSR. We repeat this procedure several times to identify a few potential core countries that influence the common factor. ${ }^{5}$ If $r>1$, then the second term should be included in Equation (12). The next selection criterion narrows the set of potential core countries to the true core countries.

Next we exclude the first core country $\tau_{1 t}^{*}$ from $\left\{\tau_{i t}\right\}_{i=1}^{N}$. Denote this panel by $\left\{\tau_{i t}\right\}_{i \neq 1}^{N}$ such that $i \in\left\{\tau_{i t}\right\}_{i \neq 1}^{N}$ if $\tau_{i t} \neq \tau_{1 t}^{*}$. If $\tau_{1 t}^{*}$ is the determinant of the first common factor, then the approximate factor model in Equation (3) can be rewritten as

$$
\tau_{i t}=\mu_{i}+\lambda_{i}^{\prime} \tau_{1 t}^{*}+\tau_{i t}^{o}, \quad i=1, \ldots, N-1
$$

so that $\tau_{i t}^{o}$ must not have any common factor. In other words, the projected residual $\hat{\tau}_{i t}^{o}$ should not have any cross-sectional dependence. If the number of factors is not estimated to be zero, then we include the second potential core country in Equation (3a), run the resulting equation with $\left\{\tau_{i t}\right\}_{i \neq 1,2}^{N}$, and test if the regression residuals have zero common factor. We continue with this procedure until the estimated number of factors becomes zero. If the estimated number of factors is zero, say after excluding the first three core countries, these three countries' transnational terrorism explains the overall cross-sectional dependence.

In sum, the whole procedure can be divided into four steps. In Step 1, the number of 
common factors is estimated. Step 2 involves estimating the common factors by using principal component analysis. The potential core countries whose transnational terrorist incidents determine the common factor are then identified in Step 3. Finally, once the potential core countries are isolated, the final selection procedure verifies if the core countries are indeed responsive to the co-movement of transnational terrorism in the world (Step 4).

\section{DATA}

Given our interest in identifying common and idiosyncratic determinants of countries’ transnational terrorist attacks, we must rely on transnational terrorist event data. We draw our transnational terrorist data from International Terrorism: Attributes of Terrorist Events (ITERATE) dataset that records the incident date, country location, and other relevant observations. ITERATE was originally devised by Mickolus (1982) and recently updated by Mickolus et al. (2009). We use transnational terrorist events throughout the world for 1970-2007 to construct a balanced panel data set, which includes most of the relevant modern era of transnational terrorism, which began in 1968 (Hoffman, 2006). Transnational terrorist incidents are generally identified by where they occurred (i.e., venue location) even when foreigners are killed. Thus, the bombing of the US Marine barracks in Lebanon on 23 October 1983 is a transnational terrorist incident in Lebanon. If there is more than one location - e.g., a skyjacking starting in France and ending in Spain, then we attribute the incident to its start location. However, for letter and parcel bombs, the incident location is where the bomb explodes or ends up.

Terrorism is the premeditated use or threat to use violence by individuals or subnational groups against noncombatants to obtain political or social objectives through the intimidation of a large audience, beyond that of the immediate victims. Terrorist acts are violence with political 
or social motives; violent acts without such motives are criminal acts and do not count as terrorism. An attack used to finance a terrorist group's campaign to induce political or social change is counted as a terrorist event. Terrorists utilize various modes of attacks - bombings, hostage taking, assassinations, suicide bombings, arson, and armed assaults - to cajole a government into giving in to their political/social demands in response to public (audience) pressure.

Terrorism is further subdivided into two categories: domestic and transnational events. Domestic events involve perpetrators, victims, and audience from just the host or venue country. In contrast, transnational terrorism concerns perpetrators, victims, or audience from two or more countries. A terrorist incident that ensues in one country and concludes in another - e.g., an international skyjacking or letter bombings - is a transnational incident. If the perpetrators plan the attack in one country and execute it in another, then the attack is a transnational terrorist incident. When the victims or perpetrators include nationalities other than that of the venue country, the incident is a transnational terrorist event. In short, transnational terrorist incidents impact the interests from at least two countries. By their nature transnational terrorism is more likely than domestic terrorism to display cross-sectional dependence.

ITERATE gathered its data on transnational terrorist incidents using a host of sources, including the Associated Press, United Press International, Reuters tickers, New York Times, Washington Post, the Foreign Broadcast Information Services (FBIS) Daily Reports, ABC, NBC, and CBS evening news. Through 1996, the FBIS Daily Reports was an invaluable source for ITERATE; these reports drew from hundreds of world print and electronic media services in many languages.

\section{EMPIRICAL RESULTS}


Table 1 displays the estimates of number of common factors for various nonzero thresholds and Information Criteria. Regardless of the threshold value, $c$, the number of factors is estimated to be one, based on IC1 and IC2. This is true for $c$ values of 2 to 6 , and all other thresholds greater than 6 . When, e.g., $c=2$, there are 106 countries with two or more periods of nonzero transnational terrorist attacks over the 38 sample years. Because the number of estimated factors is not dependent on the threshold value, the smallest threshold of 2 is chosen to estimate the common factor and factor loadings. ${ }^{6}$ As we mentioned earlier and as displayed in Table 1, IC3 overestimates the number of common factors to be four.

[Table 1 near here]

Next, we estimate the single common factor by using principal component analysis with standardized data. However, we note that the estimated common factor with standardized data is not that different than that with nonstandardized data, especially when $c$ is moderately large with a value of 6 . Hence, we use the standardized panel for the determination of the common factor in Step 2.

Before we proceed to Step 3, we analyze how well the single common factor explains the variation of the transnational terrorism in each country. To be specific, we note that the variance of the transnational terrorism in country $i, \tau_{i t}$, can be decomposed into

$$
V\left(\tau_{i t}\right)=V\left(\hat{\lambda}_{i}^{\prime} \hat{F}_{t}\right)+V\left(\hat{\tau}_{i t}^{o}\right)
$$

where $\hat{\lambda}_{i}^{\prime} \hat{F}_{t}$ is the estimate of the common component and $\hat{\tau}_{i t}^{o}$ is the estimate of the idiosyncratic component for country $i$.

[Table 2 near here]

Table 2 displays the results of the variance decomposition of the common components. We report the variances by regions (using the standard World Bank classification), and we also 
present the results for the countries with the five largest and five smallest variances. Because $\tau_{i t}$ is standardized over time, its variance for each country is always equal to one. The larger values in Table 2 are, thus, indicative of the larger dependence of a country’s (region's) transnational terrorism on a worldwide or common source of transnational terrorism. The estimate of the variance of the common component for Middle East and North Africa (MENA) is 0.154, which suggests that around $15 \%$ of transnational terrorist activities in this region are explained by a single worldwide driver of terrorism. This also implies that about $85 \%$ of transnational terrorist events in MENA are explained by idiosyncratic considerations, specific to this region. Similarly, $21 \%$ of the variation in transnational terrorist activities in Europe and Central Asia (ECA) and $16 \%$ of the variation in these terrorist activities in North America (NA) is attributed to a single worldwide driver of terrorism. In our sample, North America includes only Canada and the United States, so that the results are being largely influenced by the United States. The shares of the common component in explaining transnational terrorism in Latin America and Caribbean (LAC), South Asia (SA), sub-Saharan Africa (SSA), and East Asia and Pacific (EAP) are less than $10 \%$. A single worldwide driver of transnational terrorism explains around $71 \%$, 53\%, and 51\% of transnational terrorist activities in Lebanon, France, and Greece, respectively. However, these countries may not be determinants of the worldwide driver or common factor. We later show that transnational terrorist activities in the core countries are largely responsible for such attacks in France, Greece, Spain, and Austria. Meanwhile, transnational terrorist activities in Colombia, Liberia, Nicaragua, Guyana, and Gabon are not at all related to the worldwide common factor of transnational terrorism and are, thus, influenced by country-specific considerations.

This is a fascinating result that has, heretofore, not been shown empirically. Thus, three regions respond more to a common driver of transnational terrorism than other regions. Given 
that European capitals have been the favored venue for transnational terrorist attacks for much of the sample period, it makes sense that Europe is most influenced as a region by a common driver of transnational terrorism. Middle Eastern terrorism has spilled over to Europe throughout the period (US Department of State, various years). The top five countries affected by a common driver include Lebanon, which has been the training ground for terrorist groups from around the world, including the Red Army Faction (RAF), Hezbollah, Hamas, Abu Nidal Organization (ANO), Popular Front for the Liberation of Palestine-General Command (PFLP-GC), Palestine Liberation Front (PLF), Fatah, PFLP, Japanese Red Army (JRA), Armenian Secret Army for the Liberation of Armenia (ASALA), al-Qaida, and many others (Hoffman, 2006; Mickolus et al., 1989; US Department of State, various years). France, Greece, Spain, and Austria have been the venue for many transnational terrorist incidents during the sample period. For completeness, Table A1 in the Appendix displays the 50 countries most influenced by the common factor. It is, however, quite interesting that a terrorism-ridden country like Colombia is not affected by a worldwide driver. This result agrees with Latin America being less influenced than some other regions by a common driver. Thus, Colombia is not reflecting what has motivated transnational terrorism in other hot spots - its brand of narco-terrorism apparently sets it apart. ${ }^{7}$

Next, we proceed to Step 3 to identify the potential common factors of transnational terrorism. In particular, we apply the following estimation strategy. We begin with $m=1$ and run Equation (12) for each country, where $\sum_{j=2}^{r} \omega_{j} \hat{F}_{j t}=0$ since we have only one common factor. We run $N$ individual regressions and choose the country that gives the highest $R^{2}$. Let $\tau_{\text {st }}^{*}$ denote transnational terrorism in country $s$ that gives the greatest $R^{2}$. For $m=2$, we include $\tau_{s t}^{*}$ along with other countries' transnational terrorist events, one country at a time. This involves 
$N-1$ individual regressions. Again, we choose the second core country that provides the highest $R^{2}$. We repeat this procedure until $m=6$. We later evaluate the optimal number of $m$.

Table 3 presents the results for the potential determinants for the single common factor. We consider six countries as a set of potential determinants. The principal component estimates are always normalized to identify the factor loadings and common factors; hence, the regression coefficients can always be rescaled. In other words, we do not say that a $1 \%$ increase in transnational terrorist events in Lebanon augments the worldwide terrorism by $0.03 \%$. A more appropriate interpretation is as follows: for $m=2$, around $80 \%$ of the variation in the common driver of the transnational terrorism can be explained by transnational terrorism in Lebanon and the United States. Furthermore, Lebanon’s transnational terrorism affects worldwide comovement of terrorism by 20 percentage points more than that of the United States, because $0.03 /(0.03+0.02)=0.6$ for Lebanon, whereas $0.02 / 0.05=0.4$ for the United States - see Table 3. The other important countries in terms of explaining global transnational terrorism are Germany, Iraq, the United Kingdom, and Italy. Iraq becomes an important driver after the US invasion in 2001. The negative association for Iraq in Table 3 arises because the deployment of US forces in Iraq absorbed much of the capacity of transnational terrorists to stage attacks. ${ }^{8}$

[Table 3 near here]

It is important to note that all six countries may not be true determinants of the common factor of transnational terrorism. We, thus, proceed to Step 4. First, we construct a panel where Lebanon is deleted. That is, we check if Lebanon can explain the cross-sectional correlation for worldwide transnational terrorism. We isolate transnational terrorism in Lebanon from that in other countries and check if there is significant correlation in the residuals. Next, we ascertain whether the residuals do not contain any common factor. That is, 


$$
\tau_{i t}=a_{i}+b_{i} \tau_{t}^{*}+\varepsilon_{i t}^{*}, \text { for } i \neq \text { Lebanon, }
$$

where $\tau_{t}^{*}$ denotes terrorism in Lebanon. The set of core-country determinants of the common factor is identified once the estimated number of factors becomes zero.

[Table 4 near here]

Table 4 contains the results. Evidently, if we use IC1 and IC2 only, then we can say that Lebanon explains all cross-sectional dependence for worldwide transnational terrorism. We also checked the set of core-country determinants with various threshold values of $c$, but the result does not change - Lebanese transnational terrorism drives worldwide transnational terrorism. If we utilize IC3, which typically overestimates number of factors and the number of core countries, then we can get four additional core countries - the United States, Germany, Iraq, and the United Kingdom. Using IC3 as our criterion for core countries, we get a result nearly identical to Table 3, except for the exclusion of Italy as a core-country driver of the common factor.

An understanding of the large pivotal place that Lebanon has assumed in the modern era of transnational terrorism is reflected by its $67 \%$ role as the common driver of global transnational terrorism. This Lebanese factor has previously gone unrecognized. There are many considerations potentially behind this ignominious distinction. Since the start of the Lebanese civil war in 1975, Lebanon has not had a strong government. Consequently, terrorist groups have trained and taken safe haven in Lebanon up to the present day (Alexander and Pluchinsky, 1992; Hoffman, 2006; US Department of State, various years). As mentioned earlier, these groups included major terrorist organizations from the Middle East, Europe, and elsewhere. Many of the main state sponsors of transnational terrorism - Syria, Libya, Iran, and Iraq - have funded transnational terrorist groups in Lebanon that engaged in attacks inside and 
outside of Lebanon (Hoffman, 2006; US Department of State, various years). In Lebanon, Iran supported Hezbollah; Syria and Libya supported PFLP-GC; and Iraq supported ANO.

Hezbollah's use of large-scale suicide car bombings in 1983 against the US embassy, the US Marine barracks, and the French Paratroopers sleeping quarters influenced similar attacks in Sri Lanka, Turkey, Russia, Saudi Arabia, Yemen, and elsewhere (Bloom, 2005; Pape, 2005; Pedahzur, 2005). Israeli short-term deportation of Hamas activists to southern Lebanon in December 1992 resulted in Hamas learning the art of suicide attacks from Hezbollah. These activists then returned to Israel where suicide attacks later ensued (Hoffman, 2006). Another terrorist tactic in Lebanon that influenced transnational terrorism globally was the kidnapping of foreign aid workers, peacekeepers, academics, and diplomats for ransoms in the 1980s and 1990s. Reagan’s administration “arms-for-hostage deal” for the release of Rev. Benjamin Weir, Rev. Lawrence Jenco, and David Jacobsen resulted in the "Irangate” scandal that almost brought down the Reagan presidency and demonstrated to the rest of the world that even staunch supporters of the no-negotiation policy might renege. This resulted in increased hostage taking worldwide (Brandt and Sandler, 2009; Enders and Sandler, 2011; Mickolus et al., 1989).

Lebanon also served as the launching point for transnational terrorist attacks against Israel, which led to Israeli invasions in 1978, 1982, and 2006. These invasions subsequently sparked terrorist incidents worldwide (see, e.g., Brophy-Baermann and Conybeare, 1994; Enders and Sandler, 2012). Israeli terrorism does not play a role as a common driver of global transnational terrorism, insofar as, unlike Lebanon, most incidents in Israel are classified as domestic terrorism. Lebanon has also been the location of internecine conflict among terrorist factions - e.g., Fatah and ANO - that resulted in inter-group assassinations and attacks in Lebanon and other parts of the world - e.g., the assassination of a Fatah leader in Tunisia. US transnational terrorism is also a common driver because the Vietnam War fueled 
terrorist attacks in the United States and in Europe, where many left-wing groups (e.g., RAF, 17 November, and the Italian Red Brigades) operated. These groups not only protested the Vietnam War, but also alleged US imperialism and capitalism. Moreover, US actions in the Middle East angered many terrorist groups, leading to attacks on US soil (especially before 1990) and abroad. In a recent paper, Savun and Phillips (2009) demonstrated that unpopular foreign policy action by countries is a root cause of transnational terrorism. This finding is consistent with the United States being a driver of transnational terrorism with its presence in the Middle East and Southeast Asia. In addition, Dreher and Gassebner (2008) showed that countries that voted in line with the United States in the UN General Assembly faced a greater risk of transnational terrorism.

The German RAF served as a driver for transnational terrorism in Europe for almost 25 years. The RAF forged alliances with other groups - e.g., Direct Action in France - and cooperated with Palestinian terrorist groups (e.g., PFLP). The RAF operated in Germany, Belgium, Austria, the Netherlands, and Switzerland (Alexander and Pluchinsky, 1992). US military bases in Germany gave rise to many transnational terrorist attacks against US military personnel and dependents in Germany and elsewhere in Europe. Iraq’s presence as a common driver of transnational terrorism is more recent, following the US invasion of Iraq. Our findings then suggest that this invasion brought a new common driver, as transnational terrorists gravitated to Iraq. This was clearly not the intention of the Bush administration. Finally, the United Kingdom also had a small influence as a common driver of transnational terrorism. In the United Kingdom, the Irish Republican Army’s (IRA’s) tactics of urban warfare influenced terrorists worldwide. The IRA also forged linkages with groups in Europe and the Middle East, thereby having an influence beyond its borders (Hoffman, 2006).

Based on principal component analysis, Figure 1 displays the estimated common factor 
for transnational terrorism, and the fitted values for Lebanon $(m=1)$, Lebanon and the United States $(m=2)$, and Lebanon, the United States, and Germany $(m=3)$. The common factor is estimated in Figure 1 with nonstandardized data for two reasons. First, the estimated common factor with standardized data is heavily dependent on the choice of $c$. For small $c$, the estimated common factor with standardized data is more volatile, because the panel includes more zero observations. Second, when c is moderately large, say $c=6$, the common factor's dependence on $c$ is reduced and its estimated value is less influenced by standardization. To avoid such complications, we plot the estimated common factor without standardization. We normalize all four series in Figure 1 so that the variance of each series becomes unity; hence, standardized values are measured on the $y$-axis. From Table 3, Lebanon and the United States explain around $80 \%$ of the variation in common factor and, together with Germany, the three countries explain around $92 \%$ of worldwide co-movement of transnational terrorism. Therefore, it is not surprising that, for the most part, the fitted values for three countries' transnational terrorism series coincide well with the estimated common factor series in Figure 1. The almost perfect fit for 1993 is because Germany sustained 180 transnational terrorist attacks, which was 35\% of such attacks worldwide. Germany suffered more attacks in 1993 than in any other sample year. The only noticeable exception to this close fit is 2003-2004, after the initial phase of the "War on Terror” when al-Qaida and its affiliated groups were stressed. As shown by the aggregate common factor curve, transnational terrorism first dropped and then started to recover as the fundamentalist terrorists apparently regrouped and adjusted to the new more guarded environment.

[Figure 1 near here] 
Unlike previous empirical studies of transnational terrorism, we apply principal component analysis to identify common and idiosyncratic drivers of transnational terrorism for 1970-2007. Regardless of the sample size, we find a single common factor or driver for transnational terrorism. Some regions - e.g., Europe and Central Asia, and Middle East and North Africa - are more influenced by this common factor than other regions. Moreover, select countries - Lebanon, France, Greece, Spain, and Austria - are more affected by this common factor than other countries. In order to relate the common factor to an underlying cause, we then investigate whether a few countries' transnational terrorist campaigns determine the common driver of worldwide transnational terrorism. We used two criteria to identify the determinants of common factors or co-movements for transnational terrorism in 106 countries. The first criterion is Bai and Ng's (2002) IC2, which usually estimates the number of factors accurately. With IC2, we identified Lebanon as the most influential driver for global transnational terrorism. The second criterion is IC3, which is a more conservative measure of the determinants of the common factor. With IC3, there are five main drivers - transnational terrorism in Lebanon, USA, Germany, Iraq, and the United Kingdom - for the co-movement.

The principal component findings show how a failed or weak state - Lebanon - that gave sanctuary to numerous transnational terrorist groups from 1975 on - can impact transnational terrorism globally. Thus, failed states can generate negative spillovers of transnational terrorism far beyond their own borders. This suggests that the world community must assume a more proactive role in stabilizing these failed states in the future and assisting them to eliminate any resident transnational terrorist group. Thus, transnational terrorist campaigns in Afghanistan, Pakistan, Somalia, and Yemen may become the common drivers of transnational terrorism in the future as they serve as training bases and as the dispatch points for terrorists. This makes these seemingly far-away places the security concern of all countries whose assets - people or property 
- may be targeted by terrorists at home or abroad. Our analysis not only indicates where collective action is needed - namely, in those countries whose transnational terrorist campaigns influence such attacks worldwide (see Table 4) - but also which countries may stand to gain the most from this collective action. These participants should be those countries most affected by the common factor - see Tables 2 and A1. Countries whose transnational terrorism is primarily affected by idiosyncratic factors have little to gain from such collective action.

Indicating the countries that have the most to gain from such collective action ${ }^{9}$ is not the same as predicting whether or not such action will be taken. Countries have a marked proclivity to wait for the prime-target countries - e.g., the United States and the United Kingdom - to act against the terrorists. This free riding occurs because countries do not want to put their soldiers in harm's way or to draw new terrorist attacks in retaliation for proactive measures.

A similar principal component analysis can be applied to domestic terrorism. There is no theoretical reason why transnational and domestic terrorism will share the same drivers. In an initial analysis, we find Colombia to be the main driver of the common factor of domestic terrorism. Locating additional common factors and drivers for domestic terrorism is difficult owing to data concerns. Although a fuller analysis is planned for the future, it is interesting to note that a country - Colombia - whose transnational terrorism is almost entirely idiosyncratic is the main driver of domestic terrorism. 


\section{REFERENCES}

Abadie, A. "Poverty, Political Freedom and the Roots of Terrorism." American Economic Review, 96, 2006, 50-6.

Alexander, Y., and D. Pluchinsky. Europe's Red Terrorists: The Fighting Communist Organizations. London: Frank Cass, 1992.

Anderson, T. W. An Introduction to Multivariate Statistical Analysis. New York: Wiley, 1984.

Andrews, D. W. K. "Heteroskedasticity and Autocorrelation Consistent Covariance Matrix Estimation.” Econometrica, 59, 1991, 817-58.

Bai, J. "Estimating Cross-section Common Stochastic Trends in Nonstationary Panel Data." Journal of Econometrics, 122, 2004, 137-83.

Bai, J., and S. Ng. "Determining the Number of Factors in Approximate Factor Models.” Econometrica, 70, 2002, 191-221.

Blomberg, S., G. D. Hess, and A. Orphanides. "The Macroeconomic Consequences of Terrorism.” Journal of Monetary Economics, 51, 2004, 1007-32.

Bloom, M. Dying to Kill: The Allure of Suicide Terror. New York: Columbia University Press, 2005.

Brandt, P. T., and T. Sandler. "Hostage Taking: Understanding Terrorism Event Dynamics.” Journal of Policy Modeling, 31, 2009, 758-78.

—_. "What Do Transnational Terrorists Target? Has It Changed? Are We Safer?” Journal of Conflict Resolution, 54, 2010, 214-36.

Brophy-Baermann, B., and J. A. C. Conybeare. "Retaliating Against Terrorism: Rational Expectations and the Optimality of Rules versus Discretion.” American Journal of Political Science, 38, 1994, 196-210.

Caner, M. "Selecting the Correct Number of Factors in Approximate Factor Models: The Large 
Panel Case with Bridge Estimators.” Mimeo. North Carolina State University, Raleigh, NC, 2011.

Dreher, A., and M. Gassebner. “Does Political Proximity to the US Cause Terror?” Economics Letters, 99, 2008, 27-9.

Enders, W., and T. Sandler. “The Effectiveness of Anti-terrorism Policies: A VectorAutoregression-Intervention Analysis. American Political Science Review, 87, 1993, 82944.

—. "Distribution of Transnational Terrorism Among Countries by Income Class and Geography After 9/11.” International Studies Quarterly, 50, 2006, 367-93.

- The Political Economy of Terrorism, $2^{\text {nd }}$ Ed. Cambridge, UK: Cambridge University Press, 2012.

Gaibulloev, K., and T. Sandler. “Growth Consequences of Terrorism in Western Europe.” Kyklos, 61, 2008, 411-24.

—. "The Adverse Effect of Transnational and Domestic Terrorism on Growth in Africa." Journal of Peace Research, 48, 2011, 355-72.

Gassebner, M., R. Jong-A-Pin, and J. Mierau. “Terrorism and Electoral Accountability: One Strike, You're Out!” Economics Letters, 100, 2008, 126-9.

—. “Terrorism and Cabinet Duration.” International Economic Review, 52, 2011, 1253-70.

Gassebner, M., and S. Luechinger. “Lock, Stock, and Barrel: A Comprehensive Assessment of the Determinants of Terror.” Public Choice, 149, 2011, 235-61.

Greenaway-McGrevy, R., C. Han, and D. Sul. "Estimating the Number of Common Factors in Serially Dependent Approximate Factor Models.” Mimeo. University of Texas at Dallas, Richardson, TX.

—. "The Role of Standardization in the Estimation of Common Factors." Mimeo. 
University of Texas at Dallas, Richardson, TX.

Hallin, M., and R. Liska. "Determining the Number of Factors in the Generalized Dynamic Factor Model.” Journal of the American Statistical Association, 102, 2007, 603-7.

Hoffman, B. A. Inside Terrorism, Revised and expanded edition. New York: Columbia University Press, 2006.

Horowitz, M. C. “Nonstate Actors and the Diffusion of Innovations: The Case of Suicide Terrorism.” International Organization, 64, 2010, 33-64.

Keefer, P., and N. Loayza, eds. Terrorism, Economic Development, and Political Openness. Cambridge, UK: Cambridge University Press, 2008.

Krueger, A. B. What Makes a Terrorist? Economics and the Roots of Terrorism. Princeton, NJ: Princeton University Press, 2007.

Krueger, A. B., and J. Maleckova. "Education, Poverty, and Terrorism: Is There a Causal Connection?” Journal of Economic Perspectives, 17, 2003, 119-44.

Mickolus, E. F. International Terrorism: Attributes of Terrorist Events, 1968-1977 (ITERATE

2). Ann Arbor, MI: Inter-University Consortium for Political and Social Research, 1982.

Mickolus, E. F., T. Sandler, and J. Murdock. International Terrorism in the 1980s: A

Chronology of Events, 2 vols. Ames, IA: Iowa State University Press, 1989.

Mickolus, E. F., T. Sandler, J. Murdock, and P. Flemming. International Terrorism: Attributes of Terrorist Events (ITERATE 5). Dunn Loring, VA: Vinyard Software, Inc., 2009.

Onatsky, A. “A Formal Statistical Test for the Number of Factors in the Approximate Factor Models.” Econometrica, 77, 2009, 1447-80.

Pape, R. A. Dying to Win: The Strategic Logic of Suicide Terrorism. New York: Random House, 2005.

Pedahzur, A. Suicide Terrorism. Malden, MA: Polity Press, 2005. 
Piazza, J. A. "Poverty, Minority Economic Discrimination and Domestic Terrorism.” Journal of Peace Research, 48, 2011, 339-53.

Rapoport, D. C. “Modern Terror: The Four Waves,” in: Elements of a Grand Strategy, edited by A. K. Cronin and J. M. Cronin. Washington, DC: Georgetown University Press, 2004, 46-73.

Sandler, T., D. G. Arce, and W. Enders. “Transnational Terrorism,” in: Global Crises, Global Solutions, $2^{\text {nd }}$ Ed., edited by B. Lomberg. Cambridge, UK: Cambridge University Press, 2009, 516-62.

Savun, B., and B. J. Phillips. “Democracy, Foreign Policy, and Terrorism.” Journal of Conflict Resolution, 53, 2009, 878-904.

Tavares, J. “The Open Society Assesses Its Enemies: Shocks, Disasters and Terrorist Attacks.” Journal of Monetary Economics, 51, 2004, 1039-70.

US Department of State. Patterns of Global Terrorism. Washington, DC: US Department of State, 1987-2004.

[Table A1 near here] 


\section{Footnotes}

* We thank two anonymous reviewers for their helpful comments. This study was funded, in part, by the US Department of Homeland Security (DHS) through the Center for Risk and Economic Analysis of Terrorism Events (CREATE) at the University of Southern California, grant numbers 2007-ST-061-RE000001 and 2010-ST-061-RE0001. However, any opinions, findings, conclusions, or recommendations are solely those of the authors and do not necessarily reflect the views of DHS or CREATE.

Gailbulloev: Department of Economics, School of Business and Management, American University of Sharjah, P.O. Box 26666, Sharjah, UAE. Phone 971-6-515-2964, Fax 9716-558-5065. E-mail Khusrav_75@hotmail.com

Sandler: Department of Economics, School of Economic, Political \& Policy Sciences, University of Texas at Dallas, 800 W. Campbell Road, Richardson, TX 75080. Phone 1972-883-6725, Fax 1-972-883-6486, E-mail tsandler@utdallas.edu

Sul: Department of Economics, School of Economic, Political \& Policy Sciences, University of Texas at Dallas, 800 W. Campbell Road, Richardson, TX 75080. Phone 1-972-883-2920, Fax 1-972-883-6486, E-mail D.Sul@utdallas.edu

\footnotetext{
${ }^{1}$ Factor-augmenting panel regressions or interactive fixed-effects regressions may provide remedies. We are currently exploring this issue in a separate paper.

${ }^{2}$ There are alternative methods to estimate the number of common factors - see Caner (2011), Hallin and Liska (2007), and Onatsky (2009). We favor Bai and Ng (2002), as do many other empirical studies.

${ }^{3}$ See Greenway-McGrevy et al. (2010) and Bai (2004) for a detailed discussion.
} 
${ }^{4}$ To address this concern, we choose the smallest threshold value in the analysis that allows the procedure to go through. In so doing, we include as many countries as possible.

${ }^{5}$ Let the potential determinant, $\tau_{t}^{*}$, not be a true determinant of the common factor. Consider the single factor case, which can be expressed as

$$
\hat{F}_{1 t}=\alpha+\sum_{s=1}^{k} b_{s} \tau_{s t}+\varepsilon_{t}
$$

Suppose that $\tau_{t}^{*}=F_{t}+\tau_{t}^{o}$, where we normalize $\lambda^{*}$ to be one. In this case, it is easy to show that

$$
\tau_{i t}=\lambda_{i} F_{t}+\tau_{i t}^{o}=\lambda_{i}\left(F_{t}+\tau_{t}^{o}\right)+\tau_{i t}^{o}-\lambda_{i} \tau_{t}^{o}=\lambda_{i} \tau_{t}^{*}+e_{i t} .
$$

Hence, the residual includes one additional factor, $\tau_{t}^{o}$. To be more specific, we have

$$
\hat{e}_{i t}=\tau_{i t}-\hat{\beta}_{i} \tau_{t}^{*}=\lambda_{i} F_{t}+\tau_{i t}^{o}-\hat{\lambda}_{i} \tau_{t}^{*}=\lambda_{i} F_{t}+\tau_{i t}^{o}-\hat{\lambda}_{i} F_{t}-\hat{\lambda}_{i} \tau_{t}^{o}=\left(\lambda_{i}-\hat{\lambda}_{i}\right) F_{t}-\hat{\lambda}_{i} \tau_{t}^{o}+\tau_{i t}^{o}
$$

So as long as $\tau_{t}^{o}=O_{p}(1), \hat{e}_{i t}$ has two common factors. If $\tau_{t}^{*}$ is a true determinant of the common factor, i.e., $\tau_{t}^{*}=F_{t}$, then we have

$$
\tau_{i t}=\lambda_{i} F_{t}+\tau_{i t}^{o}=\lambda_{i} \tau_{t}^{*}+\tau_{i t}^{o},
$$

so that the regression residuals do not have any common factor.

${ }^{6}$ If $c=0$, we would be including countries with no transnational terrorism in 38 years, These countries can display no cross-sectional dependencies. For $c=1$, there is only one nonzero observation for some countries. Since the variance of the common factor has to be normalized, there must be at least two nonzero observations for determining the common factor.

${ }^{7}$ Krueger (2007) indicated that a large number of "terrorist attacks" on oil pipelines in Colombia were really nonterrorist acts of sabotage by an oil pipeline repair company. This kind of recording error can also set Colombia apart from other countries facing a common driver of transnational terrorism.

${ }^{8}$ We are grateful to an anonymous reviewer for this insight. 
${ }^{9}$ Past counterterrorism actions may influence the identification of the common factor and its core determinants, thereby affecting our policy recommendations. We, however, note that the common factor sharply declined during the Iraq war and its aftermath when international collective action was the highest. Moreover, the common factor was high in the 1980s and 1990s when there was virtually no such collective action. 
TABLE 1

Estimation of Factor Numbers and Cross-sectional Dependence

\begin{tabular}{ccccc}
\hline Threshold $\boldsymbol{c}$ & Number of countries & \multicolumn{3}{c}{ Information Criteria } \\
\hline & & IC1 & IC2 & IC3 \\
\cline { 3 - 5 } 6 & 89 & 1 & 1 & 4 \\
5 & 93 & 1 & 1 & 4 \\
4 & 95 & 1 & 1 & 4 \\
3 & 102 & 1 & 1 & 4 \\
2 & 106 & 1 & 1 & 2 \\
\hline
\end{tabular}


TABLE 2

Variance Decomposition

\begin{tabular}{lllllll}
\hline Regions & & & & & & \\
\hline MENA & ECA & LAC & SA & SSA & EAP & NA \\
0.154 & 0.214 & 0.091 & 0.048 & 0.054 & 0.050 & 0.161
\end{tabular}

Top five countries influenced by common factor

$\begin{array}{lllll}\text { Lebanon } & \text { France } & \text { Greece } & \text { Spain } & \text { Austria } \\ 0.708 & 0.525 & 0.506 & 0.484 & 0.467\end{array}$

Bottom five countries influenced by common factor Colombia Liberia Nicaragua Guyana Gabon

$\begin{array}{lllll}0.002 & 0.001 & 0.001 & 0.000 & 0.000\end{array}$

Middle East \& North Africa (MENA), Europe \& Central Asia (ECA), Latin America \& Caribbean (LAC), South Asia (SA), sub-Saharan Africa (SSA), East Asia \& Pacific (EAP), and North America (NA) 
TABLE 3

Identification of the Common Factor

\begin{tabular}{|c|c|c|c|c|c|c|c|}
\hline$m$ & $\mathbf{R}^{2}$ & Lebanon & USA & Germany & Iraq & UK & Italy \\
\hline 1 & 0.670 & $\begin{array}{l}0.031 \\
(4.39)\end{array}$ & & & & & \\
\hline 2 & 0.806 & $\begin{array}{l}0.029 \\
(7.56)\end{array}$ & $\begin{array}{l}0.019 \\
(3.62)\end{array}$ & & & & \\
\hline 3 & 0.916 & $\begin{array}{l}0.027 \\
(10.7)\end{array}$ & $\begin{array}{l}0.019 \\
(5.53)\end{array}$ & $\begin{array}{l}0.012 \\
(4.96)\end{array}$ & & & \\
\hline 4 & 0.956 & $\begin{array}{l}0.026 \\
(15.3)\end{array}$ & $\begin{array}{l}0.016 \\
(6.95)\end{array}$ & $\begin{array}{l}0.011 \\
(7.07) \\
\end{array}$ & $\begin{array}{l}-0.009 \\
(-4.53)\end{array}$ & & \\
\hline 5 & 0.984 & $\begin{array}{l}0.026 \\
(34.5) \\
\end{array}$ & $\begin{array}{l}0.015 \\
(14.5) \\
\end{array}$ & $\begin{array}{l}0.010 \\
(14.2) \\
\end{array}$ & $\begin{array}{l}-0.008 \\
(-9.08) \\
\end{array}$ & $\begin{array}{l}0.009 \\
(8.55) \\
\end{array}$ & \\
\hline 6 & 0.991 & $\begin{array}{l}0.025 \\
(38.6)\end{array}$ & $\begin{array}{l}0.012 \\
(11.0)\end{array}$ & $\begin{array}{l}0.010 \\
(17.4)\end{array}$ & $\begin{array}{l}-0.008 \\
(-11.3)\end{array}$ & $\begin{array}{l}0.008 \\
(9.21)\end{array}$ & $\begin{array}{l}0.010 \\
(5.40)\end{array}$ \\
\hline
\end{tabular}

Numbers in parentheses are $t$-statistics based on the long run variance by Andrews (1991) 
TABLE 4

Remaining Core Countries for Transnational Terrorism

\begin{tabular}{cccccc}
\hline & Number of & & \multicolumn{3}{c}{ ICs } \\
\cline { 4 - 6 } $\boldsymbol{c}$ & countries & Core countries & IC1 & IC2 & IC3 \\
\hline 2 & 106 & & 1 & 1 & 2 \\
& & Lebanon & 0 & 0 & 3 \\
& & US & 0 & 0 & 1 \\
& Germany & 0 & 0 & 1 \\
& Iraq & 0 & 0 & 1 \\
& UK & 0 & 0 & 0 \\
\hline 3 & 102 & & 1 & 1 & 4 \\
& & Lebanon & 0 & 0 & 3 \\
& & US & 0 & 0 & 2 \\
& & Germany & 0 & 0 & 1 \\
& & Iraq & 0 & 0 & 1 \\
& & UK & 0 & 0 & 0 \\
\hline 4 & & & 1 & 1 & 4 \\
& & Lebanon & 0 & 0 & 3 \\
& & US & 0 & 0 & 2 \\
& & Germany & 0 & 0 & 1 \\
& & Iraq & 0 & 0 & 1 \\
& & UK & 0 & 0 & 0 \\
\hline
\end{tabular}


FIGURE 1

Estimated Common Factor and Its Determinants

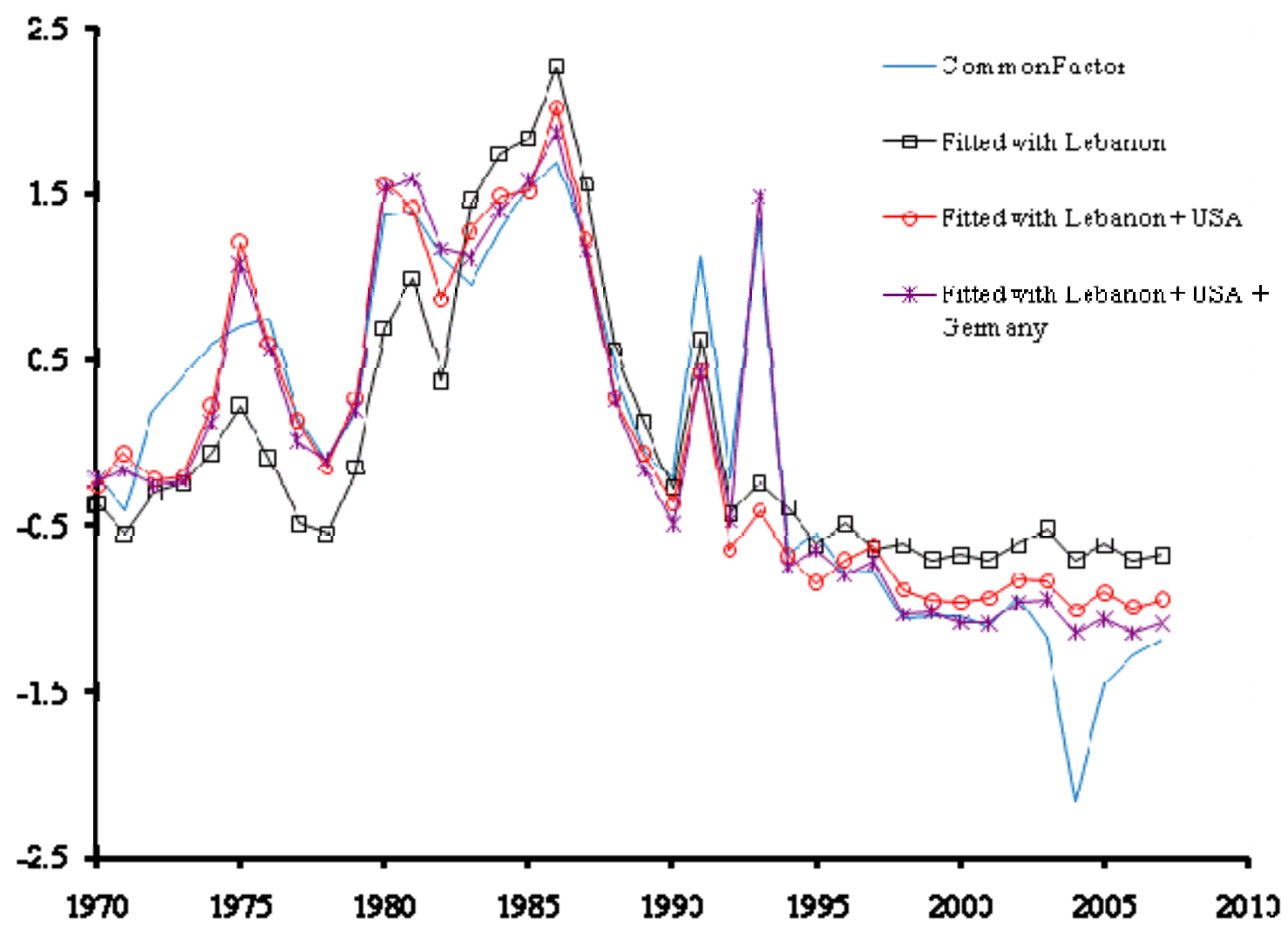




\section{Appendix}

TABLE A1

\begin{tabular}{clc|clc}
\hline \multicolumn{5}{c}{ Top 50 Countries Affected by Common Factor } \\
\hline Rank & \multicolumn{1}{c}{ Country } & $\begin{array}{c}\text { Variance of the } \\
\text { common component }\end{array}$ & Rank & \multicolumn{1}{c}{ Country } & $\begin{array}{c}\text { Variance of the } \\
\text { common component }\end{array}$ \\
\hline 1 & Lebanon & 0.708 & 26 & Poland & 0.212 \\
2 & France & 0.525 & 27 & Congo, Republic of & 0.198 \\
3 & Greece & 0.506 & 28 & Netherlands & 0.196 \\
4 & Spain & 0.484 & 29 & Nigeria & 0.182 \\
5 & Austria & 0.467 & 30 & Iran & 0.176 \\
6 & Cyprus & 0.404 & 31 & Romania & 0.176 \\
7 & Peru & 0.400 & 32 & Philippines & 0.161 \\
8 & Honduras & 0.370 & 33 & Zambia & 0.160 \\
9 & Costa Rica & 0.348 & 34 & Central African Rep. & 0.159 \\
10 & Japan & 0.333 & 35 & Malta & 0.159 \\
11 & Guatemala & 0.323 & 36 & Botswana & 0.151 \\
12 & Switzerland & 0.304 & 37 & Belgium & 0.150 \\
13 & Luxembourg & 0.300 & 38 & United States & 0.149 \\
14 & Italy & 0.296 & 39 & Singapore & 0.143 \\
15 & Portugal & 0.293 & 40 & Lesotho & 0.141 \\
16 & Tunisia & 0.257 & 41 & Brazil & 0.133 \\
17 & Ecuador & 0.249 & 42 & Jamaica & 0.128 \\
18 & Swaziland & 0.247 & 43 & Zimbabwe & 0.127 \\
19 & El Salvador & 0.235 & 44 & Iceland & 0.124 \\
20 & Sweden & 0.232 & 45 & Burkina Faso & 0.124 \\
21 & Korea, Republic of & 0.231 & 46 & Kuwait & 0.118 \\
22 & Chile & 0.222 & 47 & Bolivia & 0.117 \\
23 & Canada & 0.218 & 48 & Australia & 0.116 \\
24 & Afghanistan & 0.218 & 49 & Sierra Leone & 0.115 \\
25 & Syria & 0.214 & 50 & Saudi Arabia & 0.114 \\
\hline
\end{tabular}

Idiosyncratic variance $=1-$ (variance of the common component) 